\title{
Microzyman Theory of Origin (MTO)/ Cellular Dust Hypothesis (CDH)-Matters Arising
}

\author{
Seun Ayoade* \\ Department of Physiology, University of Ibadan, Nigeria
}

Received: 制September 22, 2018; Published: 制 September 27, 2018

*Corresponding author: Seun Ayoade, UNICEF Certified Health Educator, Tel: +2348060221764; University of Ibadan, Nigeria

\section{Opinion}

The microzyman theory of the origin of the universe (MTO) otherwise called The Cellular Dust Hypothesis $(\mathrm{CDH})$ is now not well known. But as a rational and forward-thinking scientist I anticipate some of the criticisms that will attend the theory in the future when (hopefully) it becomes as well known as the theories of Evolution or Intelligent Design viz:

\section{Harmonization Criticism}

That MTO was invented to reconcile evolutionists and creationists by giving them a mid-way explanation satisfactory to both parties.

Refutation: I stand alone. I never intended to convert or pacify either Creationists or

Evolutionists. All I seek are facts. All I seek is to understand and interpret the world around me to the best of my ability. If Evolutionists or Creationists imbibe or integrate the Microzyman Theory so be it. I never intended to convert, approve or disprove either Evolutionists or Creationists. I stand alone and have no godfather manipulating me from behind the shadows. The idea came to me, like greased lightning completely out of the blue early one morning.

\section{Irreligion/Atheism Criticism}

That MTO was invented to destroy people's faith in religion.

Refutation: MTO is a scientific theory. Science deals with fact. Religion deals with faith. The

MTO is not trying to replace God with microzymas. Microzymas never exceed 500 nanometer in size. A Supreme Being would have to transcend space. So, the very idea of MTO theory trying to substitute/replace God and religion is silly. Galileo once said mathematics was the language God used to write the universe.
If that's the case I declare that the microzymas are the pens and pencils God used to do the writing.

\section{Star Wars Criticism}

That MTO stole the Midichlorian concept in the movie Star Wars Phantom Menace [1999]

Refutation: Midichlorians are fictional microscopic life forms that reside in cells. The

midichlorians of the movie are symbionts. Microzyma are not symbionts. In symbiosis (mutualism) one organism cannot survive without the other. Microzyma don't need any organisms to survive. Microzyma are immortal as far as can be determined. Microzyma MAKE cells-not live as symbionts with them! Plus, when cells die, microzyma remain alive and kicking. Microzyma were discovered and documented roughly a century before George Lucas was born. If at all anyone stole anything, it would be the writers of Star Wars phantom Menace who borrowed the microzyman concept.

\section{Anaxagoras Criticism}

That MTO was stolen from the ancient Greek philosopher Anaxagoras. Anaxagoras said that life sprang from atmospheric germs/seeds. Microzyma are not germs. Microzyma MAKE germs. The concepts are slightly similar but fundamentally different.

\section{Panspermia Criticism}

That MTO is a reworking of the Panspermia Theory popularized by Fred Hoyle, Svante Arrhenius, Hermann Richter, Francis Crick, Leslie Orgel etc. In panspermia micro-organisms from another planet via meteors etcetera served as seeds creating life on earth. In MTO, the microzyma made the micro-organisms, set off the Big Bang, made the entire universe, planets, light, mountains, the sun, moon etc. MTO and panspermia are fundamentally different. 
(c) C) This work is licensed under Creative

To Submit Your Article Click Here: $\quad$ Submit Article

DOI: $10.32474 /$ PRJFGS.2018.02.000141

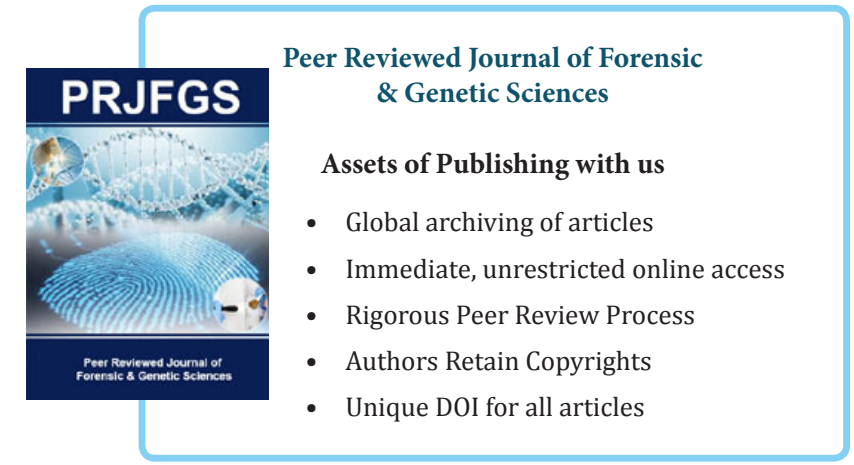

